\title{
PENDIDIKAN MODERASI BERAGAMA UNTUK GENERASI MILENIA: STUDI KASUS 'LONE WOLF' PADA ANAK DI MEDAN
}

\section{RELIGIOUS MODERATION EDUCATION FOR THE MILENIAN GENERATION: A CASE STUDY 'LONE WOLF'IN CHILDREN IN MEDAN}

\author{
Elma Haryani \\ Badan Litbang dan Diklat Kementerian Agama \\ email: elmaharyani@kemenag.go.id
}

Naskah Diterima: 27 Desember 2019; Direvisi: 23 Agustus 2020; Disetujui: 25 Agustus 2020

\begin{abstract}
This article discusses the phenomenon of the development of intolerance in religion, especially that afflicting young people. This study aims to seek input for the development of family-based moderation education. This study used qualitative research, with a case study approach to the incidence of attacks by young people on a priest delivering a sermon at the St. Joseph Church in Medan. This study concludes that children's acts of religious violence are motivated by the teachings of radicalism read on the internet. This research recommends that it is time for agitative religious lectures, hate speech, cyber-net terrorism to be intervened by the state through relevant regulations and supervision. Also, parents need to increase awareness of the negative impact of technology and build more togetherness by developing moderate religious values in the family.
\end{abstract}

Keywords: Family education; Intolerance; Lone wolf; Moderation education

\begin{abstract}
Abstrak
Artikel ini membahas tentang fenomena perkembangan paham intoleransi dalam beragama, khususnya yang menimpa anak muda. Penelitian ini bertujuan untuk mencari masukan pengembangan pendidikan moderasi berbasis keluarga. Penelitian ini menggunakan penelitian kualitatif, dengan pendekatan studi kasus pada kejadian penyerangan oleh anak muda pada pastor yang sedang menyampaikan khutbah di Gereja Santo Joseph Medan. Penelitian ini menyimpulkan bahwa tindakan kekerasan agama oleh anak-anak dimotivasi oleh ajaran radikalisme yang dibaca di internet. Penelitian ini merekomendasikan bahwa sudah saatnya ceramah keagamaan sepihak, pidato kebencian, terorisme melalui cyber-net perlu diintervensi oleh negara melalui regulasi dan pengawasan yang relevan. Selain itu, orang tua perlu meningkatkan kewaspadaan dampak negatif teknologi dan membangun lebih banyak kebersamaan dengan mengembangkan nilai-nilai agama yang moderat dalam keluarga.
\end{abstract}

Kata Kunci: Intoleransi; Lone wolf; Pendidikan moderasi; Pendidikan keluarga 


\section{PENDAHULUAN}

Kota Medan sebagai kota metropolitan tidak sepi dari letupan kejadian intoleransi beragama. Beberapa bentuk intoleransi di Medan misalnya serangan yang menyasar beberapa gereja di kota Medan Sumatera Utara, Mei 2000 (Fealy and Borgu, 2005). Di tahun yang sama, serangan yang menargetkan gereja di Medan, Pematang dan Siantar dan beberapa kota lain di Indonesia terjadi pada malam Natal 2000 (Peter Chalk, Angel Rabasa, William Rosenau, 2010). Fakta ini memperlihatkan bahwa Medan menjadi daerah di mana aktivitas terorisme dan jaringannya perlu mendapat perhatian serius. Perilaku intoleran ternyata tidak saja menghinggapi orang dewasa, tetapi juga terjadi juga pada anak. Di Kota Medan, seorang anak 19 tahun seorang diri berani melakukan serangan terhadap pastor sedang menyampaikan khotbah di Gereja Santo Joseph Medan. Kasus terakhir ini dikategorikan 'lone wolf, yaitu peristiwa teror yang dilakukan perseorangan, tidak ada jaringan dan tanpa komando dari pihak lain.

Peristiwa ini cukup mengagetkan semua pihak mengingat motivasi serangan ini bukan dihasilkan dari dorongan provokator dengan pelaku, namun lebih dihasilkan dari akses internet secara mandiri dan menghasilkan keberanian seorang anak melakukan aksi penyerangan sendirian. Istilah 'lone wolf' meski relatif baru dan jarang ditemukan dalam beberapa referensi diasosiasikan dengan sebuah fenomena kejahatan kekerasan yang dipopulerkan oleh Alex Curtiz dan Tom Metzger pada tahun 1990 untuk agenda politik tertentu. Di mana sebuah kelompok tertentu membentuk, mendorong dan mengarahkan seseorang untuk melakukan kejahatan kekerasan. Saat ini term 'lone wolf' menjadi popular di berbagai negara terutama kaitannya dengan isu terorisme dan tentu saja media sangat punya pengaruh besar untuk menyebarluaskan term tersebut. Beberapa indikasi 'lone wolf' dapat di tandai dengan tiga hal sebagaimana disebutkan oleh Spaaij dalam bukunya yang berjudul 'Understanding Lone wolf Terrorism' bahwa; .... 'mereka (a) beroperasi secara individual, (b) tidak terkait dengan sebuah organisasi teroris atau jaringan tertentu, dan (c) modus operasi dilakukan secara langsung sendirian oleh pelaku tanpa komando langsung dari luar ataupun tanpa hirarki.'(Anis, 2016)

Berbicara tentang intoleransi keagamaan pada anak, kajian-kajian yang pernah dilakukan dan dapat dipetakan di antaranya dilihat dari: pertama dari penyebab anak jatuh pada perilaku intoleransi seperti masalah krisis identitas, beberapa sekolah yang kurang kontrol, terlibat dalam lone wolf (Wahyu Akmaliah Muhammad and Pribadi, 2013; Hilmy, 2015; Jafar, Sudirman and Rifawan, 2019); kedua nilai-nilai moderasi beragama yang perlu dikembangkan pada anak muda sebagai jalan keluar membendung kecenderungan radikalisasi beragama (Mussafa, 2018; Aziz, 2020; Hiqmatunnisa and Zafi, 2020); ketiga, model pendekatan pendidikan yang bisa digunakan dalam mencegah kecenderungan radikalisme pada anak muda (Futaqi, 2018; Murtadlo, 2019b; Sutrisno, 2019; Khotimah, 2020). Qowaid (2013) juga pernah menulis tentang gejala intoleransi di kalangan peserta didik dan upaya penanggulangannya melalui pendidikan agama di sekolah. Secara umum, kajian kali ini mengambil bagian dari membaca kecenderungan pertama yaitu penyebab intoleransi pada anak, dan mencoba membaca kemungkinan ketiga tentang model pendekatan pendidikan moderasi yang dibangun di luar pendidikan formal seperti sekolah, namun kembali pada pendidikan berbasis keluarga.

Dalam konteks peta konsep seperti itu, tulisan ini akan mengkaji fenomena perilaku intoleransi agama pada anak dengan mengambil kasus 'Penyerangan terhadap Gereja Santo Joseph di Medan dilihat dari perspektif pendidikan anak'. Pertanyaan penelitian dirumuskan untuk menjawab bagaimana mencegah perilaku intoleran terjadi pada anak. Untuk menjawab pertanyaan ini, rumusan masalah dirinci dengan pertanyaan bagaimana deskripsi keagamaan di Kota Medan, deskripsi kejadian intoleransi pada kasus di Gereja Santo Medan. bagaimana kecenderungan intoleransi beragama di Kota Medan, dan bagaimana kemungkinan pendidikan moderasi beragama dibangun dalam konteks pendidikan keluarga.

Penelitian ini menjadi penting untuk mengantisipasi kecenderungan perilaku intoleransi pada anak muda di masa mendatang. 
Tindakan radikalisme keagamaan yang terjadi di Kota Medan ini penulis berhipotesa disebabkan karena akses internet demikian terbuka di satu sisi, di sisi lain pengawasan orang tua kurang memadai dan anak mendapatkan pendidikan keagamaan yang tidak pas. Tujuan penelitiaan, pertama, untuk mendeskripsikan bentuk 'lone wolf' yang terjadi di Gereja Santo Joseph Medan; Kedua, untuk mengetahui respons masyarakat terhadap perilaku intoleransi pada anak; Ketiga, untuk membaca celah berkembangnya paham intoleran pada anak; Keempat, untuk merumuskan peran keluarga dalam pendidikan moderasi beragama pada anak.

\section{KAJIAN TEORI}

Kecenderungan literatur mengenai intoleransi agama oleh anak pada tulisan ini kita kelompokkan menjadi tiga bahasan, yaitu kepustakaan tentang penyebab intoleransi keagamaan pada anak, nilai-nilai yang diperlukan dalam pengembangan moderasi beragama pada anak, dan model pendekatan pendidikan moderasi beragama pada anak.

Kajian mengenai penyebab intoleransi pada anak misalnya disebutkan Wahyudi Akmaliah Muhammad dan Khelmy K. Pribadi yang meneliti Anak Muda, Radikalisme, dan Budaya Populer. Menurut para pengkaji, di tengah-tengah tidak mudahnya menetapkan definisi kaum muda, tindakan teror dan bom bunuh diri yang dilakukan oleh lulusan sekolah menengah muda menunjukkan bahwa ada masalah mengenai identitas diri sebagian dari warga negara dan juga bagian dari komunitas Muslim Indonesia. Pecahnya fenomena islamisasi ruang publik yang ditandai oleh tiga hal (gerakan, radikalisasi, dan budaya populer) setidaknya menjawab mengapa sikap benihbenih radikalisme dapat tumbuh di kalangan anak muda (Wahyudi Akmaliah Muhammad and Pribadi, 2013).

Fanani menyebutkan bahwa penyebab lain intoleransi pada anak muda adalah sekolah yang kurang melakukan kontrol terhadap paham keagamaan yang berkembang di kalangan siswa. Sekolah menjadi ruang yang terbuka bagi diseminasi paham apa saja. Karena pihak sekolah terlalu terbuka, maka kelompok radikalisme keagamaan memanfaatkan ruang terbuka ini untuk masuk secara aktif mengampanyekan pahamnya dan memperluas jaringannya. Kelompok-kelompok keagamaan yang masuk mulai dari yang ekstrem hingga menghujat terhadap negara dan ajakan untuk mendirikan negara Islam, hingga kelompok Islamis yang ingin memperjuangkan penegakan syariat Islam (Fanani, 2013). Hal ini diperkuat oleh Zuly Qadir, bahwa akar-akar radikalisme di sekolah akan sangat mungkin muncul karena sekolah merupakan arena yang sangat potensial. Sekolah sebagai arena akan menemukan titik perkembangannya ketika di sana didapatkan adanya (modal sosial) seperti suntikan dari para agency untuk mendapatkan pemahaman keagamaan yang radikal itu sendiri (Zuly Qodir, 2013).

Salah satu celah kecolongan besar munculnya perilaku radikal pada anak muda disebabkan juga oleh kelemahan guru dari pendidikan dasar hingga menengah. Guru mempunyai jam interaksi dengan murid dalam jumlah yang banyak dimulai dari usia dini hingga pendidikan jenjang menengah. sedikit saja guru membiarkan peserta didik mempunyai paham intoleran pada saat mengenyam pendidikan sekolah, maka tindakan pembiaran ini akan menyumbang perkembangan paham intoleran di kalangan anak muda lebih lanjut (Murtadlo, 2019a).

Mengenai nilai-nilai yang sebaiknya dikembangkan dalam menekan angka intoleransi, kajian Musaffa menyebutkan bahwa perlunya mengembangkan nilai al wasatiyah sebagaimana disebutkan dalam Q.S al-Baqarah ayat 143. Kata al wasatiyah terambil dari akar kata yang pada mulanya berarti: "tengah-tengah di antara dua batas, atau dengan keadilan, yang tengah-tengah atau yang standar atau yang biasa-biasa saja". Menurutnya, moderasi beragama tidak dapat tergambar wujudnya kecuali setelah terhimpun dalam satu kesatuan empat unsur pokok, yaitu kejujuran, keterbukaan, kasih sayang dan keluwesan (Mussafa, 2018).

Aziz menambahkan bahwa belajar dari kasus pesantren Situbondo, jiwa moderat dalam melihat persoalan agama tertanam pada para santri karena mereka memiliki pengetahuan yang baik dalam bidang fikih dan ushul fiqh. Dalam bidang fikih mereka sudah terbiasa 
dengan perbedaan, dalam diri mereka sudah terbangun bahwa perbedaan adalah sebuah keniscayaan, sehingga perbedaan harus dihadapi dengan kebijaksanaan bukan kemarahan. Ketika menghadapi perbedaan dalam fikih maka analisanya menggunakan ushul fikih (Aziz, 2020).

Kajian mengenai model pendekatan pendidikan moderasi beragama, misalnya dinyatakan Muhammad Ahnaf menyatakan bahwa tantangan lembaga pendidikan Islam dalam mempromosikan nilai toleransi dan penghargaan terhadap keragaman agama terletak tidak sebatas persoalan kurikulum, melainkan pada kemampuan otoritas sekolah dalam mengelola lingkungan dan ruang publik sekolah yang mendorong kebebasan dan tradisi berpikir secara kritis. Otoritas sekolah perlu memahami materi dan pola-pola penyebaran paham radikal di kalangan anak muda, terutama di lingkungan sekolah, sehingga potensi pengaruh paham radikal bisa diantisipasi secara efektif (Ahnaf, 2013: 169).

Muhammad Najib Azca melakukan penelitian dengan judul 'The Younger, the Radical: Refleksi Sosiologis pada Fenomena Radikalisme Muslim Muda di Indonesia Pasca Orde Baru'. Dia mengusulkan salah satu cara terbaik untuk melawan gerakan keagamaan radikal pada orang muda adalah dengan menerapkan strategi ganda, yaitu mengembangkan diskusi kritis dan membangun wacana counter, ide dan narasi, dan mendukung dan mengembangkan hubungan sosial dan jaringan jamak (Azca, 2013).

\section{METODOLOGI}

Metode penelitian yang digunakan dalam penelitian ini adalah kualitatif dalam bentuk studi kasus. Kasus yang dipilih adalah kasus terpaparnya seorang anak terhadap perilaku intoleransi di Medan. Kasus 'lone wolf' di Kota Medan ini dipilih dengan pertimbangan: pertama, kasus intoleransi ini terjadi pada seorang diri anak muda, yang dengan kesendiriannya dia berani melakukan penyerangan terhadap pastor yang sedang berkhotbah; kedua Kota Medan adalah kota metropolitan di Pulau Sumatera dan mempunyai keragaman sosial yang tinggi. Terjadinya kasus intoleransi pada anak menjadi menarik di tengah kota multikultural seperti Medan Sumatera Utara ini.

Jenis data yang dibutuhkan dalam penelitian ini adalah data deskripsi tentang konteks, latar belakang, kejadian dan referensi mengenai kasus di atas. Pengumpulan data dilakukan baik di lapangan maupun dengan searching internet dan kepustakaan. Teknik pengumpulan data dilakukan dengan mengunjungi lokasi kejadian, wawancara, dan penelusuran informasi melalui internet dan kepustakaan. Informan yang dijadikan narasumber terdiri dari pelaku serangan, pastor (korban penyerangan) pengelola sekolah di mana pelaku menempuh pendidikan, tokoh agama di lingkungan Kementerian Agama Kota Medan.

Penelitian dilakukan selama kurang lebih tiga bulan pada tahun 2016. Di mulai dengan tahapan persiapan yang dilakukan di Jakarta, kunjungan ke lapangan yaitu di tempat kejadian Kota Medan yang dilaksanakan selama 7 hari. Selebihnya pasca pengumpulan data di lapangan, penjaringan informasi dilanjutkan penelusuran melalui internet dan daftar pustaka dan terakhir analisa dan penulisan laporan.

Analisa dilakukan dengan cara deskriptif analisis. Deskripsi digunakan untuk menggambarkan kejadian dan respons masyarakat di Kota Medan; analisis dilakukan dengan mengembangkan kasus dalam konteks munculnya perilaku intoleran pada anak dan kemungkinan pencegahannya melalui pendidikan moderasi pada keluarga.

\section{HASIL DAN PEMBAHASAN}

\section{Deskripsi Keragaman dan Intoleransi Beragama di Kota Medan}

Kota Medan dikenal sebagai kota dengan tingkat kemajemukan yang tinggi. Kota ini bahkan menempati peringkat kota-kota yang termajemuk di Indonesia. Tingginya tingkat kemajemukan ini memang berpotensi pada munculnya konflik-konflik. Potensi konflik Sumatera Utara sangat dimungkinkan terjadi karena banyak faktor, salah satu di antaranya adalah kompetisi dalam memperebutkan sumber daya ekonomi dan politik di daerah. Ketimpangan dalam distribusi sumber daya ekonomi maupun politik, adanya hegemoni atau 
dominasi suatu kelompok etnik dalam penguasaan sumber daya publik potensial menjadi faktor-faktor disintegratif yang bisa memicu konflik etnik (Muda, 2013).

Tabel 1. Data demografi keagamaan Provinsi Sumatera Utara

\begin{tabular}{lrr}
\hline Agama & Jumlah & Prosen \\
\hline Islam & 8.579 .830 & 66,09 \\
Kristen & 3.509 .700 & 27,03 \\
Katolik & 516.037 & 3,97 \\
Hindu & 14.644 & 0,11 \\
Buddha & 303.548 & 2,34 \\
Konghucu & 984 & 0,01 \\
Lain-lain & 5.088 & 0,04 \\
\hline
\end{tabular}

Sumber : Data Sensus Penduduk (BPS, 2010)

Realitas kemajemukan di Sumatera Utara terbilang unik di mana dengan tingkat kemajemukan masyarakat yang sangat tinggi tapi tingkat kerukunan masyarakatnya cukup tinggi juga. Kemajemukan masyarakat di wilayah ini bahkan kerap dianggap sebagai ikon kerukunan di Indonesia. Terciptanya suasana kerukunan di Sumatera Utara tidak terlepas dari upaya-upaya yang dilakukan oleh tokoh-tokoh masyarakat dan agama di Sumatera Utara. Secara institusional, keberadaan beberapa kelompok misalnya Forum Komunikasi Umat Beragama (FKUB), Forum Lintas Pemuda, dan Forum Lembaga Adat dan Budaya (Forkala) adalah di antara unsur-unsur masyarakat yang menopang bagi terciptanya suasana kerukunan masyarakat di Sumatera Utara.

Banyak program kerukunan dilakukan oleh kelompok-kelompok ini misalnya dalam bentuk seminar dan pertemuan lintas agama dan budaya. Kegiatan-kegiatan ini umumnya didukung oleh pemerintah setempat melalui anggaran-anggaran pembangunan yang ada. Secara formal pembinaan kerukunan melalui dialog-dialog antar agama ini memang telah menjadi program nasional Pemerintah Pusat melalui Kementerian Agama. Pemerintah Indonesia dalam hal ini menjadikan kerukunan beragama sebagai salah satu program pembangunan yang telah digariskan dalam GBHN.

Di samping hal tersebut di atas ada satu hal tidak kalah pentingnya yang menjadi salah satu faktor kuat pendukung kerukunan di Medan adalah kearifan lokal (local wisdom) masyarakat Sumatra utara yang dimaknai sebagai gagasan-gagasan setempat yang bersifat bijaksana, penuh kearifan, bernilai baik, dan tertanam sekaligus diikuti oleh anggota masyarakatnya. Dalam antropologi dikenal istilah local genius yang pertama dikenalkan oleh H.G Quaritch Wales, selanjutnya dikembangkan oleh F.D.K. Bosch. Local genius merupakan identitas kultural bangsa yang menyebabkan bangsa tersebut mampu menyerap dan mengolah kebudayaan asing sesuai watak dan kemampuan sendiri. Adapun dalam konteks masyarakat Sumatera Utara, kearifan lokal dapat dilihat dalam beberapa komunitas. Unsur budaya daerah pada dasarnya berpotensi sebagai local genius karena telah teruji kemampuannya untuk bertahan dengan ciri-ciri sebagai berikut: (1) Mampu bertahan terhadap budaya luar; (2) Memiliki kemampuan mengakomodasi unsur-unsur budaya luar; (3) Mempunyai kemampuan mengintegrasikan unsur budaya luar ke dalam budaya asli; (4) Mempunyai kemampuan mengendalikan; dan (5) Mampu memberi arah pada perkembangan budaya. Mengaitkan pengertian local wisdom dengan local genious jelas memiliki tujuan yang relevan. Dalam pengembangan budaya, local wisdom yang diharapkan adalah elemen-elemen yang tidak hanya mampu bertahan tapi juga harus mampu memberikan kontribusi bagi perkembangan kebudayaan tapi juga bagi peradaban yang lebih luas (Ayatrohaedi, 1986: 40-41).

Dalam komunitas Batak, sebagai representasi suku lokal di Sumatera Utara, dikenal istilah adat Dalihan $\mathrm{Na}$ Tolu, yaitu filosofi atau wawasan sosial budaya yang berfungsi merekatkan relasi sosial, walaupun berbeda agama dan etnis. Begitupun dalam 
komunitas Melayu, terdapat nilai-nilai yang sarat dengan petuah yang bijak untuk menjunjung tinggi persatuan dan kesatuan bangsa.

Di samping itu Kebijakan pemerintah Kota Medan merupakan elemen yang tak kalah pentingnya bagi terciptanya kerukunan umat beragama. Dengan memberikan dukungan baik itu berupa pidato yang menghimbau masyarakat Kota Medan tentang pentingnya kerukunan maupun bantuan yang berupa finansial agar terlaksananya kegiatan-kegiatan keagamaan, bersikap adil dengan semua agama, dan membentuk jaringan yang berupa organisasi Forum Kerukunan Umat Beragama, menunjukkan peran yang dimainkan oleh pemerintah Kota Medan dalam membina kerukunan di Kota Medan agar tetap rukun dan harmonis. Gubernur Sumatera Utara juga memberikan dukungan yang seimbang terhadap kegiatan-kegiatan kemasyarakatan yang bernuansa keagamaan, seperti misalnya, Festival Ramadhan, Christmas Session, dan Imlek Fair serta festival-festival keagamaan lainnya. Kedekatannya dengan berbagai kelompok agama dan gaya komunikasinya yang akrab membuat suasana hubungannya dengan kelompok-kelompok agama relatif lebih cair.

Namun kota medan tidak berarti sepi dari letupan kejadian intoleransi. Beberapa aktivitas intoleransi di Medan dapat dilihat misalnya serangan yang menyasar beberapa gereja di kota Medan Sumatera Utara pada bulan Mei 2000 (Fealy \& Borgu, 2005:27). Di tahun yang sama juga, serangan yang menargetkan gereja di Medan, Pematang dan Siantar di Sumatera Utara beserta dan juga di beberapa kota lain di Indonesia terjadi pada malam Natal tanggal 24 Desember 2000 (Chalk et al., 2009:98). Fakta ini memperlihatkan bahwa Medan menjadi daerah di mana aktivitas terorisme dan jaringannya perlu mendapat perhatian serius

Beberapa pemicu munculnya tindakan intoleransi, penelitian Faisal Nurdin Idris menyebutkan bahwa konstruksi narasi Islamisme yang ditemukan di Medan terdiri dari narasi militan terkait kebencian terhadap Yahudi dan Nasrani, ketidaksukaan terhadap Ahmadiyah dan aliran sesat, dan ketidaksenangan terhadap Islam liberal dan Syiah. Narasi radikalisme yang terbalut dalam framing antagonis mencakup Islam versus demokrasi, dan penerapan syariah Islam dan pendirian negara Islam versus sistem yang berlaku saat ini di Indonesia. Narasi ekstremisme terbangun tidak saja pada pandangan yang pro dan simpati terhadap penggunaan kekerasan, namun juga termanifestasikan pada tindakan penyerangan dengan menggunakan kekerasan terhadap kelompok masyarakat lainnya. Terakhir, walaupun secara umum narasi terorisme kurang mendapat tempat dalam masyarakat Medan yang ini ditandai dengan penolakan terhadap aksi teroris, namun narasi terorisme muncul dalam narasi perang jihad dan mati syahid yang diperbolehkan dalam kasus di Ambon dan di Poso, serta situasi perang seperti di Afghanistan dan di Palestina (Idris, 2015: 39).

\section{Kasus Serangan Anak Muda atas Pastor di Gereja Santo Joseph Medan}

Salah seorang Guru Besar Psikologi Universitas Indonesia (UI) Hamdi Muluk mengatakan pencegahan terhadap bahaya radikalisme, termasuk pada anak muda, sudah harus lebih keras lagi, karena telah terbukti aksi radikalisme meningkat setiap tahun di mana setiap tahunnya mengalami kenaikan antara 2-3 persen. Hal tersebut adalah hal yang harus diantisipasi serius oleh pemerintah karena menurut Hamdi masalah radikalisme dan terorisme tidak dapat dipisahkan dari lingkungan sosial, politik, ekonomi dan budaya di mana ideologi terorisme itu tumbuh dan berkembang. Menurutnya, terorisme merupakan hasil dari proses radikalisasi mulai dari level individu hingga kelompok. Pada kelompok teroris yang mengatasnamakan agama, proses tersebut meliputi praradikalisasi, identifikasi diri, komitmen dan indoktrinasi, dan ideologisasi jihad (Muluk, 2016).

Salah satu kejadian intoleransi tiba-tiba saja muncul dan menambah daftar kejadian intoleransi di Medan. Kejadian itu berbentuk serangan seorang anak muda terhadap seorang pastor yang sedang berkhotbah di Gereja Santo Joseph. Pelaku adalah seorang anak yang masih berusia 19 tahun. Kejadian ini sekaligus memunculkan pertanyaan bagaimana si anak mendapatkan paham radikal seperti itu. Bagaimana cara transfer pahamnya, dan 
sekaligus apa yang salah dari sistem sosial yang berkembang saat ini.

\section{Kejadian penyerangan berlangsung} begitu cepat, yaitu pada hari Minggu (28 Agustus 2016) sekitar jam 08.45 di saat Misa Kudus di Gereja Santo Joseph yang berada di daerah Jl. Dr. Mansyur, Medan Selayang, Medan. Pelaku yang kebetulan masih berusia muda sudah duduk terlebih dahulu di barisan ketujuh. Ketika sang Pastor Albertus Pandiangan mulai membacakan ayat Injil (Lukas 14; 1.7-14)' tiba-tiba terdengar letupan dan percik api dari ransel pelaku. Pelaku terlihat jelas karena dalam posisi duduk sementara yang lainnya dalam posisi berdiri. Panik karena ada percikan api dalam tas ransel, pelaku langsung berlari dengan bubuk mesiu yang berceceran di lantai menuju altar di mana pastor berada. Pelaku berjalan sambil mengacungkan kampak ke arah Pastor. Akan tetapi sebelum pelaku sampai di tempat sang Pastor berdiri, pelaku berhasil diamankan oleh umat.

Kontan ketika pastor merasa terancam, ia berlari ke arah umat. Namun naas beliau terjatuh sehingga menimpa sebuah kipas angin besar yang berdiri dan melukai lengan pastor. Lengan pastor terluka. Namun berdasarkan kesaksian Natalia dan Benar Ginting, luka yang ada di lengan pastor tersebut bukan karena ulah pelaku penyerangan. Karena sebelum sempat jadi korban, pelaku menurut para saksi mata sama sekali bukan karena dilukai oleh pelaku karena pelaku diamankan oleh umat dengan cepat.

Umat Katolik di Kota Medan sama sekali tidak menyangka kejadian ini akan terjadi, apalagi pelaku sangat membaur dan terlebih dahulu masuk gereja. Benar Ginting Munti (Plt. ketua Dewan Stacy Pastoral Santo Joseph) menandaskan bahwa jauh sebelumnya tidak ada persoalan antara umat beragama di lingkungan gereja Santo Joseph, secara khusus dan di wilayah Medan secara umum (wawancara, tanggal 31 Agustus 2016). Meskipun ada sedikit kejanggalan karena dia sendiri yang memakai celana training, padahal ada peraturan di dalam gereja tidak boleh menggunakan baju yang tidak formal ataupun tidak sopan. Saat itu tidak ada satupun yang curiga bahwa ransel yang dibawa pelaku itu adalah bom rakitan. Umat Katolik yang tengah melakukan ibadah misa saling bersitegang dalam hal memperlakukan pelaku yang tertangkap. Ada yang memukulinya dan hampir membunuhnya, hanya saja sebagian umat mengingatkan agar tidak melakukan kekerasan dan pembalasan di dalam gereja yang sakral. Akhirnya menurut Natalia dan suaminya yang merupakan penjaga dan pelayan umat di gereja tersebut kemudian pelaku diamankan sambil menunggu pihak kepolisian yang sedang menuju tempat kejadian.

Sejam kemudian pihak kepolisian yang datang ke tempat kejadian. Meski sempat ditanya oleh pihak gereja kenapa datang agak 'terlambat' dijawab bahwa itu sesuai prosedur di kepolisian karena harus memastikan banyak hal sebelumnya. Selanjutnya pelaku dibawa ke Polresta Medan untuk dilakukan investigasi dan penyelidikan terkait kejadian penyerangan tersebut. Sehari setelah kejadian tersebut tepatnya pada hari senin 29 Agustus 2016, kasus penyerangan tersebut diserah terima kan penyelidikannya dari Kapolresta Medan Kombes H. Mardiaz Kusin Dwihananto di dampingi oleh Wakalporesta yang baru menjabat sejak bulan Mei yang lalu yaitu AKBP Mahendi Surenda dan Kasatreskrimnya Kompol Fahrizal kepada Tim investigasi Komandan Detasemen Khusus anti-teror (Densus 88) yang merupakan pasukan elit Mabes Polri yang bertugas khusus utnuk menanggulangi terorisme dan penegakan hukum domestik Indonesia di mana Densus 88 terdiri dari para ahli investigasi, tim lapangan termasuk tim gegana dan penembak jitu; diharapkan mampu meredam terorisme di Indonesia untuk menjaga keamanan dan stabilitas negara.

Pelaku ditetapkan sebagai tersangka penyerangan pastor di Gereja Katolik Santo Joseph jalan Dr. Mansyur Medan pada minggu 28 Agustus 2016 kemudian polisi menggeledah rumahnya di kelurahan Tanjung sari, kecamatan Medan Selayang. Pemeriksaan itu menemukan barang bukti berupa detonator rakitan, trafo, pipa, semen, alumunium foil, baterai, paspor, kartu tanda siswa, kabel-kabel, pupuk urea dan buku-buku tentang robotik. Sebenarnya pada tanggal 26 Agustus 2016 malam, kakak perempuan pelaku mendengarkan suara ledakan dari kamar adiknya. Dari hasil pemeriksaan, 
pelaku terindikasi sedang melakukan percobaan terhadap bom pipa yang dirakitnya (Andalas, 1 September 2016).

Secara formal keluarga pelaku meminta maaf terhadap umat Katolik khususnya dan masyarakat pada umumnya dan mengaku salah karena tidak bisa mengawasi dan mendidik anaknya dengan baik (Republika, 2 September 2016). Pada kesempatan yang lain ketua Cabang Peradi Medan yang didampingi ketua pusat Bantuan Hukum (PUSBAKUM) siap mendampingi keluarga pelaku sebagai bagian dari keluarga besar profesi pengacara dan menyediakan 30 pengacara.

Kejadian radikalisme pada anak di Medan di atas sontak mengundang keprihatinan para pemuka agama dan masyarakat di Kota Medan. Maratua Simanjuntak (Ketua FKUB Sumatra Utara), sehari setelah kejadian penyerangan kemudian mengumpulkan semua tokoh agama dan masyarakat yang terdiri dari; Majelis-majelis Agama Sumut dan Kota Medan; FKUB Sumut dan Kota Medan, Kanwil Kemenag; Badan Kesbangpolinmas, pada hari Senin 29 Agustus 2016. Pertemuan ini menghasilkan keputusan penting bahwa: 1) peristiwa yang terjadi di Gereja Katolik Santo Josephh, Jl. Dr. Mansyur Medan disepakati tidak ada kaitannya dengan SARA atau bukan masalah keagamaan tetapi kriminal yang menjadi urusan kepolisian; 2) Bersama-sama menjaga sarana dan prasarana rumah ibadah di Sumut dari gangguan pihak yang tidak bertanggungjawab; 3) Mendukung proses penegakan hukum secara tuntas terhadap semua peristiwa yang mengganggu kerukunan umat beragama di Sumut; 4) Bersepakat menjaga kondusifitas Sumut yang sudah dikenal di Indonesia dan menolak segala bentuk anarkisme, radikalisme dan terorisme; 5) Berharap kepada Media Massa dan Media Sosial turut menjaga kerukunan umat beragama di Sumut.

Peristiwa yang tadinya dianggap sebagai kriminal biasa, selanjutnya berubah menjadi isu terorisme. Pada saat yang bersamaan, semua pihak dihimbau secara proaktif Kemenag juga diminta untuk mulai 'peka' dan antisipatif dengan banyaknya kasus radikalisme yang berbau SARA. Pada tanggal 30 Agustus 2016, kasus tersebut kemudian dilimpahkan dan diserahkan ke Densus 88 oleh Kasatreskrim. Kombes Pol Mardiaz, Kapolresta Medan, mengingatkan agar masyarakat Medan mulai lebih berhati-hati agar tidak mudah terprovokasi dengan banyaknya kejadian berbau SARA, terutama jika itu ada kaitannya dengan isu teror berkedok agama. Banyaknya kelompok pengajian yang cenderung 'eksklusif' ada baiknya mulai di imbangi dengan banyak mudzakarah yang terbuka di masjid-masjid. Siapa yang paling diuntungkan dalam kejadian-kejadian seperti ini dan siapa yang mungkin bermain dan 'mengail di air keruh' adalah pertanyaan yang harus selalu dicari jawabannya.

Pendapat lain, disampaikan Pastur John Ruvenus (Dewan Paroki Santo Antonius Medan) yang mengatakan bahwa kejadian tersebut adalah: 1) peristiwa ini merupakan suatu 'cobaan' bagi kita semua, oleh karena itu hendaklah tetap konsisten untuk tetap berbuat baik agar kejadian ini tidak terulang kembali; 2) Orang-orang yang berada dalam kepengurusan FKUB nampaknya harus lebih kuat dan kompak dalam merawat kerukunan; 3) Masing-masing keluarga harus memperhatikan keluarganya, agar anak-anak khususnya tidak gampang di masuki oleh pemahaman yang salah dan destruktif, keluarga adalah 'pagar pertama' yang harus benar-benar sadar betul terhadap pengawasan dan pendidikan anak (wawancara, 31 Agustus 2016)

Pendapat yang terakhir ini lebih mengedepankan introspeksi kepada semua pihak terkait dengan kejadian radikalisme oleh anak. Semua pihak dihimbau kembali untuk menguatkan kembali pendidikan keluarga sebagai tempat penanaman nilai moderasi pada anak. Keluarga menjadi kunci dalam mengontrol perilaku sosial, khususnya pada anak. Perkembangan teknologi menjadikan komunikasi orang tua dengan anak tergantikan oleh teknologi media sosial. Orang tua dan anak mulai jarang membicarakan berbagai permasalahan yang terjadi pada lingkungan sosial di sekitarnya.

\section{Melacak Akar Motivasi Kejadian Intoleransi}

Anis dalam hasil kajiannya menyebutkan bahwa ada empat faktor analisis kenapa generasi milenial potensial untuk ditarget oleh teroris, yaitu faktor neurologi 
(yaitu terkait berkembangan anak menuju dewasa), konteks keluarga (seperti keluarga yang tidak harmoni atau broken), konteks sosial (seperti terjadinya marginalisasi, ketimpangan ekonomi); perkembangan tehnologi yang cepat menyebarkan paham transnasional (Anis, 2016: 204-205). Bagaimana kemungkinan akar masalah lone wolf di Kota Medan ini.

Secara umum berdasarkan analisa Kapolresta Medan, Kombes Pol Mardiaz Kusin Dwihananto, pelaku berani melakukan tindakan intoleransi nampaknya terpengaruh karena melihat berita dari internet tentang ledakan bom yang terjadi di Prancis (Gunawan, 2016), namun pihaknya belum dapat memaparkan lebih jauh terkait aksi teror yang dilakukan pelaku karena masih dalam penyelidikan pada waktu itu, artinya ada pengaruh dari dunia maya dalam membentuk pola pikir pelaku penyerangan. Peneliti sempat diberi harapan oleh kapolresta untuk bisa langsung bertemu dengan pelaku akhirnya pada hari kelima dipastikan oleh kasareskrim tidak boleh bertemu dengan pelaku karena pihak Densus 88 keberatan dan khawatir proses investigasi yang sudah dilakukan sejak paska kejadian akan terpecah-pecah fokusnya jika ada in-depth interview dari peneliti atau pihak selain Densus 88. Di terima oleh Kombes Wahyu (Ketua Tim Investigasi Densus 88) hampir selama sekitar 2 jam usaha untuk menemui langsung pelaku meski ahirnya tidak bisa ketemu pelaku karena terhambat prosedur.

Di samping pertimbangan di atas pihak Densus 88 juga sedang diburu oleh waktu karena pelaku masuk kategori anak jadi terikat dengan UU SPPA; Undang-Undang Nomor 11 Tahun 2012 tentang Sistem Peradilan Pidana Anak, UU SPPA ini merupakan pengganti dari Undang-Undang Nomor 3 Tahun 1997 tentang Pengadilan Anak yang bertujuan agar dapat terwujud peradilan yang benar-benar menjamin perlindungan kepentingan terbaik terhadap anak yang berhadapan dengan hukum. UU SPPA mendefinisikan anak di bawah umur sebagai anak yang telah berumur 12 tahun tetapi belum berumur 18 tahun. Adapun substansi yang diatur dalam UU SPPA antara lain mengenai penempatan anak yang menjalani proses peradilan dapat ditempatkan di Lembaga Pembinaan Khusus Anak (LPKA). Substansi yang paling mendasar dalam Undang-Undang ini adalah pengaturan secara tegas mengenai Keadilan Restoratif dan Diversi yang dimaksudkan untuk menghindari dan menjauhkan anak dari proses peradilan sehingga dapat menghindari stigmatisasi terhadap anak yang berhadapan dengan hukum dan diharapkan anak dapat kembali ke dalam lingkungan sosial secara wajar. Demikian antara lain yang disebut dalam bagian Penjelasan Umum UU SPPA. Keadilan Restoratif merupakan suatu proses Diversi, yaitu semua pihak yang terlibat dalam suatu tindak pidana tertentu bersama-sama mengatasi masalah serta menciptakan suatu kewajiban untuk membuat segala sesuatunya menjadi lebih baik dengan melibatkan korban, anak, dan masyarakat dalam mencari solusi untuk memperbaiki, rekonsiliasi, dan menenteramkan hati yang tidak berdasarkan pembalasan. Diversi adalah pengalihan penyelesaian perkara anak dari proses peradilan pidana ke proses di luar peradilan pidana.

Pada kasus pelaku serangan terhadap pastor di Gereja Santo Medan, dalam proses penyidikan, Densus 88 berharap sebelum minggu kedua semua motivasi dan bagaimana mind set pelaku akan dapat di urai. Sampai hari yang ke enam, pelaku masih banyak diam dan tidak mau berterus terang. Ada kekhawatiran bahwa pelaku masuk dalam jejaring yang lebih besar. Keterangan dan kejujuran pelaku menjadi sangat signifikan untuk ditelisik lebih dalam dan detail agar dapat memotong 'mata rantai' jaringan. Di sarankan untuk penelitian yang terkait pelaku terror agar ada 'surat tugas khusus' yang ditujukan pada komandan tertinggi Densus 88 agar dapat mewawancarai langsung dari awal. Selanjutnya setelah 2 minggu ke depan pelaku direncanakan akan dibawa ke Jakarta. Dari Kombes Wahyu juga di dapatkan informasi bahwa ada dua pelaku yang masih masuk kategori anak berada di rutan Salemba terjaring kasus teror juga.

Selama menjalani investigasi pelaku juga dipertemukan dengan seorang mantan teroris yaitu Khairul Ghazali (Pimpinan PP. Darussyifa, Kutalimbaru Deli Serdang Sumut) mantan terpidana perampokan Bank CIMB Niaga untuk mengkonfirmasi apakah pelaku adalah bagian dari sebuah jaringan besar atau 
berdiri sendiri. Sebuah harian lokal (Andalas, 01 September 2016) menyebutkan kemungkinan adanya keterkaitan pelaku dengan jaringan kelompok teroris yang lebih besar lewat internet. Khairul Ghazali khawatir bahwa adanya pelaku-pelaku muda lainnya yang berpotensi melakukan 'amaliyat Jihad' karena pengaruh 'cuci otak' lewat internet. Menurutnya, sel-sel jihadist di Medan sudah lama beraksi dan masih aktif; mulai dari komando jihad 1976, pembajakan GARUDA woyla 1981, peledakan gereja tahun 2000, perampokan LIPPO Bank tahun 2003, perampokan Bank SUMUT tahun 2009, perampokan BANK CIMB Niaga dan penyerangan polsek Hamparan Perak 2010.

Dari penelusuran latar belakang keluarga pelaku, pelaku adalah seorang anak muda yang berusia belum genap 18 tahun, pelaku adalah anak ketiga dari pasangan pengacara dan PNS ini termasuk memiliki karakter introvert dan cenderung tidak suka bersosial sebagaimana anak-anak muda pada umumnya. Ayah pelaku adalah seorang advokat yang sering beracara di Pengadilan Negeri Medan dan sekaligus bertindak sebagai kuasa hukum bagi anaknya tersebut. Berangkat dari kejadian yang menimpa anak ketiganya tersebut pengacara senior itu meminta pengawasan dunia maya diperketat. Dia tidak ingin anak-anak lain mendapat pengaruh negatif dari dunia maya meski tentu saja ada sisi positifnya. Ayahnya berpendapat bahwa anaknya adalah 'korban' dari orang-orang yang mempengaruhi anaknya memalui internet serta melakukan brain washing terhadap anaknya yang pada awalnya hanya sekedar punya hobi bermain internet. Sejak dua tahun terakhir pelaku terlihat berubah pola pikir dan perilakunya bahkan terkadang sering bertengkar dengan kakaknya karena tidak mau dinasihati terutama perihal akidah.

Di lingkungan sekolah, menurut Humas SMA 04 (wawancara, 1 September 2016), pelaku adalah murid yang tidak menonjol secara akademik tapi sangat taat terhadap agama. Ketaatan tersebut terlihat dari kebiasaannya di sekolah yang selalu menunaikan salat tepat pada waktunya. Pada saat waktu salat tiba, maka dia akan segera mengangkat tangan minta izin untuk salat. Dia juga termasuk taat menjalankan ibadah sunah, yaitu ketika tiba waktu dhuha, maka dia juga akan bergegas menjalankan salat sunah dhuha. Terhadap lawan jenis, anak ini tidak mau bersalaman dengan perempuan. Sehari-hari lebih banyak menghabiskan waktunya dengan memainkan ponsel. Dalam riwayat Bimbingan Konseling (BK) pelaku tidak punya catatan khusus selain pernah sekali dipanggil oleh BK karena tidak masuk sekolah beberapa hari. Sifat tertutup (introvert) dan tidak suka bergaul dengan banyak orang nampak nyata pada tahun terakhir. Bahkan pelaku tidak mau mengikuti kegiatan ekstrakurikuler sama sekali walaupun ada sejenis kegiatan keagamaan sekalipun seperti unit Kerohaniawan Islam (Rohis).

Dari aspek lain, yaitu akses terhadap media, interaksi pelaku yang sangat intens dengann ponsel dan dunia internet diduga kuat menjadi pintu masuk berubahnya mind-set pelaku dari layaknya anak remaja biasa menjadi seorang radikalis. Awalnya berasal dari followers twitter kemudian lama kelamaan terjerat masuk jaringan media sosial para kelompok radikal (hasil wawancara dengan AKBP Kombes Wahyu, tim investigasi Densus 88, Jumat, 2 September 2016), sampai hari keenam pelaku belum mau menyampaikan apa motivasi dibalik rencana peledakan bom di gereja tersebut.

Dari awal sejak kasus penyerangan gereja Santo Joseph ini terjadi, di berbagai media Jenderal Polisi Tito Karnavian (Kepala Kepolisian RI) dan Menpolhukam Jenderal Wiranto sudah mengatakan bahwa kasus ini memiliki indikasi yang kuat sebagai bagian dari bentuk 'lone wolf'. Ini seiring dengan gerakan Bahrun Naim, dari kelompok Khatibah Nusantara, yang melakukan rekruitmen terhadap anak-anak remaja di bawah 18 tahunan untuk dilatih dengan menggunakan bahanbahan yang sederhana dan tersedia dengan mudah di sekitar mereka untuk membuat bom dan melakukan aksi teror secara individual. Pun tidak ada dukungan dari eksternal dalam melakukan hal tersebut (tempo, 05/09/2016 dan the balitimes.com 11/08/2016). Hal tersebut selaras dengan penjelasan Khairul Ghazali (salah seorang mantan teroris) yang sempat dipertemukan dengan pelaku penyerangan pelaku oleh Densus 88 dalam rangka menelisik keterkaitan pelaku dengan jaringan teroris yang 
lebih besar. Pada saat itu menurut Khairul Ghazali, pelaku sempat menyebut nama Bachrun Naim dan melihat bagaimana video pelaku yang berbaiat terhadap pimpinan ISIS Abu Bakar Al-Baghdadi (Andalas, 01/09/2016).

Dari perspektif korban, Pastor Albertus Pandiangan meski mengaku sangat shock dengan kejadian ini, sebagai korban penyerangan baik secara personal maupun kelembagaan beliau telah memaafkan pelaku. Dia berasumsi bahwa pelaku masih mungkin untuk dididik dan dibina kembali ke jalan yang benar mengingat usia pelaku yang masih muda. Beliau juga mengingatkan dengan tegas pentingnya keluarga sebagai 'gereja kedua' yang seharusnya mengawasi anak-anak agar tidak terjerumus pada sikap dan aksi kekerasan sebagai akibat dari media dan internet. Peristiwa seperti ini sudah pasti tidak hanya merugikan diri sendiri melainkan merugikan banyak pihak. Pastor Albertus percaya bahwa tidak ada satu agama manapun yang mengajarkan kekerasan dan pembinasaan bahkan secara tegas Pastor mengatakan beliau percaya bahwa ISIS itu bukan Islam, melainkan menggunakan Islam sebagai kedok atau mengatasnamakan Islam.

Ke depan agar kasus seperti pelaku ini tidak terulang kembali Pastor menganjurkan agar meningkatkan dan memperbanyak program-program 'pembinaan umat' masingmasing agama, serta ada kerja sama yang jelas dan regular antar umat beragama, dalam hal ini peran FKUB menjadi harus lebih ditingkatkan dan harus lebih 'down to earth'. Boleh jadi menurut pastor maraknya kasus kekerasan Di samping kurang pembinaan mental-spiritual, juga dipicu oleh kecemburuan sosial. Sehingga kecemburuan ini melahirkan keputusasaan yang bisa memicu adanya sikap agresif yang melahirkan kekerasan atasnama apapun. Kebetulan motif agama menjadi faktor pemicu yang paling fragile (wawancara, Rabu, tanggal 31 Agustus 2016). Selaras dengan yang disampaikan oleh Pastor Albertus lebih jauh sebuah buku yang berjudul 'Islamict Terrorism and Militancy in Indonesia' yang ditulis oleh $\mathrm{K}$. Ramakrisna (Springer, 2015) mengulas tentang banyak hal yang menjadi pemicu sebuah aksi teror dan motif agama ataupun ideologi sama sekali bukanlah satu-satunya motif. Untuk itu butuh kajian dan analisa yang lebih komprehensip.

\section{Revitalisasi Keluarga sebagai Lembaga Pendidikan Moderasi}

Pada sub bahasan ini, penulis mencoba menawarkan pentingnya menghidupkan kembali peran keluarga dalam menangkal kemungkinan anak muda terpapar dalam radikalisme agama. Orang tua perlu mewaspadai dampak negatif dari internet dari kemungkinan paham transnasional yang merugikan keharmonisan hubungan beragama di Indonesia. Serta orang tua perlu aktif mengajak diskusi secara bermartabat tentang berbagai pemikiran keagamaan dan anak diajak untuk berpikir solutif terhadap berbagai persoalan sosial yang ada. Anak diajak untuk berpikir yang terbaik yang bisa diberikan kepada bangsa.

Belajar dari kasus-kasus intoleransi seperti penyerangan bernuansa keagamaan seperti yang terjadi di gereja Santo Joseph di Medan, dan peristiwa-peristiwa lain seperti Nana Mulyana dan Dani Permana (kasus JW. Marriot), Nur Rohman (kasus Solo), Teuku Umar (kasus Aceh); menunjukkan bahwa fenomena lone wolf di kalangan anak muda sudah tidak bisa lagi dianggap kejadian sepele. Perlu keterlibatan semua elemen untuk lebih serius melakukan pencegahan dan pembinaan serta kampanye yang terus menerus terkait hal tersebut. Fenomena lone wolf yaitu peristiwa penyerangan yang terjadi dalam bentuk (a) beroperasi secara individual, (b) tidak terkait dengan sebuah organisasi teroris atau jaringan tertentu, dan (c) modus operandi nya secara langsung dilakukan sendirian tanpa komando langsung dari luar ataupun tanpa hirarki merupakan peristiwa tak terduga yang bisa terjadi di mana saja. Karena itu, kemungkinan terjadinya lone wolf saat ini perlu mendapatkan perhatian dari semua pihak baik orang tua, masyarakat maupun lembaga pendidikan.

Murtadlo (2019a) dalam kajian tentang moderasi beragama pada lembaga pendidikan keagamaan pesantren dan Seminari di Jawa Timur (2019) merekomendasikan perlunya pendidikan moderasi beragama dikenalkan kepada anak muda sedini mungkin. Hal ini penting agar sedini mungkin anak muda Indonesia mengenal perbedaan, keragaman dan 
siap untuk hidup bersama (Murtadlo, 2019b). Peran guru sekolah sangat penting dalam mengenalkan moderasi beragama di sekolah. Sedikit guru agama memberi peluang berkembangnya paham intoleran, maka hal itu akan menyumbang berkembangnya radikalisme agama di masyarakat secara luas.

Dalam menanggapi kasus penyerangan di Gereja Santo Joseph yang melibatkan seorang anak di Medan, beberapa pihak yang berhasil peneliti wawancarai mencoba menganjurkan pentingnya membangun pendidikan keluarga sebagai lembaga pengontrol sekaligus pelaku pendidikan moderasi beragama. Hal itu dinyatakan seperti oleh FKUB Provinsi Sumatera Utara, Pastur John Ruvenus (Dewan Paroki Santo Antonius Medan), termasuk Pastor Albertus Pandiangan (korban langsung dari penyerangan ini). Mereka sepakat bahwa pendidikan keluarga perlu dioptimalkan lagi dalam rangka mereda perilaku intoleransi pada anak (wawancara 31 Agustus 2016).

Badan Nasional Penanggulangan Terorisme (BNPT), menyatakan sudah saatnya anak-anak muda diawasi dari kemungkinan keterpaparan dalam paham radikalisme. Utamanya terkait dengan aktivitas mereka di dunia maya. ia menjelaskan bahwa di era kemajuan teknologi informasi seperti saat ini, ajaran-ajaran radikal mudah disebarkan melalui internet. Karenanya beliau meminta agar anakanak muda selalu di awasi orang tua minimal harus tahu situs-situs apa saja yang sering diakses oleh anak-anaknya, jangan sampai mereka menjadi radikal karena mengakses internet tanpa ada pengawasan. Lebih lanjut BNPT mengatakan bahwa perkembangan internet membuka celah bagi masuk dan berkembangnya paham radikal, anak-anak muda yang mengakses informasi-informasi radikal itu disebutnya berpeluang sangat besar untuk menjadi radikal atau bahkan menjadi pelaku teror. Meski begitu beliau juga menyatakan bahwa internet tidak sepenuhnya buruk, karena melalui internet pula informasi yang baik dan benar terkait dengan agama dan nasionalisme dapat disebarluaskan ke masyarakat (BNPT, 2016).

Diantara pemikiran yang mencoba melontarkan pemikiran tentang pendidikan moderasi beragama pada anak muda, misalnya Masdar Hilmi yang menyampaikan: Pertama, negara perlu hadir mendesain materi dan metode deradikalisasi yang relevan dengan karakteristik psikologis anak muda. Harus diakui, program deradikalisasi di negeri ini kurang mengakomodasi metode serta materi yang menggugah, inspiratif, dan relevan dengan kebutuhan psikologis-intelektual anak muda. Sebab, target program deradikalisasi selama ini adalah kelompok usia dewasa. Kedua, perluasan jangkauan program deradikalisasi ke wilayah-wilayah yang selama ini dianggap privat seperti keluarga. Program deradikalisasi oleh BNPT selama ini hanya menyentuh ormasormas keagamaan dewasa yang jumlahnya terbatas. Dalam konteks ini, jumlah anak muda yang tidak terlibat dalam program deradikalisasi jauh lebih banyak. Ketiga, mengatasi dislokasi dan deprivasi sosial anakanak muda melalui program pelibatan sosial. Selama ini, proses kognitif dan psikologis anak muda kurang terawasi dengan baik oleh orangorang dewasa di sekitarnya. Mereka menjadi radikal karena komunikasi sosial mereka dengan orang-orang terdekat terputus. Solusinya, anak muda harus sesering-seringnya diajak berdialog dan berkomunikasi dengan orang dewasa (Hilmy, 2015)

\section{PENUTUP}

Berdasarkan kajian ini, ada beberapa yang menarik digarisbawahi. Pertama, pelaku penyerangan terhadap Pastor di gereja Santo Joseph Medan adalah seorang anak muda yang besar kemungkinan terjadi akibat dampak perkembangan teknologi yang cepat yang memudahkan seorang anak menangkap ide atau paham keagamaan secara personal (tanpa guru). Kedua, seiring perkembangan media, berkembang pula paham keagamaan yang radikal yang mudah diakses dan dikonsumsi pelaku. Ketiga, beberapa pemuka agama, tokoh masyarakat, aparatur keamanan memandang perlu pengembangan pendidikan moderasi beragama berbasis keluarga.

Kajian ini merekomendasikan: pertama, perlunya pendidikan moderasi beragama di kembangkan dalam lingkungan keluarga. Kedua, beberapa teknis pendidikan moderasi beragama yang bisa dilakukan orang tua antara lain sering-sering orang tua mengajak dialog secara terbuka pada anak untuk membangun sikap moderat dalam paham keagamaan anak; 
serta dalam beberapa kesempatan ajaklah anak untuk bersosial untuk menumbuhkan sikap empati anak terhadap berbagai masalah sosial dan diajak berpikir memecahkan permasalahan sosial.

\section{UCAPAN TERIMA KASIH}

Atas telah selesainya penelitian dan penulisan artikel ini, penulis merasa perlu mengucapkan terima kasih kepada pimpinan Puslitbang Bimas Agama dan Layanan Keagamaan yang telah membiayai penelitian ini. Di lapangan kami berterima kasih kepada beberapa pihak yang telah menerima dan bersedia diwawancarai dalam proses pengumpulan data. Mereka itu adalah Pastor korban penyerangan, Dewan Paroki Santo Antonius Medan, Humas SMA 04 Medan, Densus 88. Atas kerja sama mereka, penelitian ini berhasil dilakukan.

\section{DAFTAR PUSTAKA}

Ahnaf, M. I. (2013) 'Struktur politik dan deradikalisasi pendidikan agama bagi anak muda di Indonesia', Jurnal Pendidikan Islam. doi: 10.14421/jpi.2013.21.153-171.

Anis, E. Z. (2016) 'Countering Terrorist Narratives:Winning the Hearts and Minds of Indonesian Millennials', in The 1st International Conference on South East Asia Studies, 2016. KnE Social Sciences, pp. 189-210. doi: 10.18502/kss.v3i5.2333.

Ayatrohaedi (1986) Kepribadian Budaya Bangsa (Local Genius). Jakarta: PT Dunia Pustaka Jaya.

Azca, M. N. (2013) 'Yang Muda, Yang Radikal: Refleksi Sosiologis Terhadap Fenomena Radikalisme Kaum Muda Muslim di Indonesia Pasca Orde Baru', Maarif, 8(1), pp. 14-44.

Aziz, A. (2020) 'Akar Moderasi Beragama Di Pesantren (Studi Kasus di Ma'had Aly Sukorejo Situbondo dalam Terbentuknya Nilai-Nilai Moderasi Beragama)', ArRisalah: Media Keislaman, Pendidikan dan Hukum Islam. doi: 10.29062/arrisalah.v18i1.348.
BNPT (2016) Terkait Lone Wolf, kepala BNPT Minta Awasi Anak Muda. Available at: https://damailahindonesiaku.net/terkaitlone-wolf-kepala-bnpt-minta-awasianak-muda.html.

BPS (2010) Penduduk Menurut Wilayah dan Agama yang Dianut. Available at: https://sp2010.bps.go.id/index.php/site/ta bel?tid=321 \&wid=0.

Fanani, A. F. (2013) 'Fenomena Radikalisme di Kalangan Kaum Muda', Maarif: Arus Pemikirian Islam dan Sosial.

Fealy, G. and Borgu, A. (2005) Local Jihad: radical Islam and terrorism in Indonesia. Australian Strategic Policy Institute.

Futaqi, S. (2018) 'Konstruksi Moderasi Islam (Wasathiyyah) Dalam Kurikulum Pendidikan Islam', in 2nd Proceedings Annual Conference for Muslim Scholars, pp. 521-530.

Gunawan, A. (2016) Medan church attacker inspired by France attack: Police. Available at: https://www.thejakartapost.com/news/20 16/08/29/medan-church-attackerinspired-by-france-attack-police.html.

Hilmy, M. (2015) 'Anak Muda di Tengah Pusaran Radikalisme', Jawa Pos, 27 March. Available at: http://digilib.uinsby.ac.id/14245/1/Anak Muda Di Tengah Pusaran Radikalisme .pdf.

Hiqmatunnisa, H. and Zafi, A. A. (2020) 'Penerapan Nilai-Nilai Moderasi Islam Dalam Pembelajaran Fiqih Di PTKIN Menggunakan Konsep Problem Basic Learning', JIPIS. doi: 10.33592/JIPIS.V29I1.546.

Idris, F. N. (2015) 'Memetakan Narasi Islamisme Di Medan, Sumatera Utara: Investigasi Terhadap Pola Penyebaran Dan Penerimaan Terhadap Radikalisme', Jurnal Ilmu Politik dan Komunikasi, V(2), pp. 25-40. Available at: https://repository.unikom.ac.id /30950/1/jurnal-3-fix.pdf. 
Jafar, T. F., Sudirman, A. and Rifawan, A. (2019) 'Ketahanan Nasional Menghadapi Ancaman Lone Wolf Terrorism Di Jawa Barat', Jurnal Ketahanan Nasional, 25(1), pp. 73-91. doi: https://doi.org/10.22146/jkn.41244.

Khotimah, H. (2020) 'Internalisasi Moderasi Beragama Dalam Kurikulum Pesantren', Rabbani: Jurnal Pendidikan Agama Islam. doi: 10.19105/rjpai.v1i1.3008.

Muda, Indra. (2013) 'Potensi Konflik Horizontal di Kota Medan', Jurnal Perspektif. 6(2), pp. 138-144

Muhammad, Wahyudi Akmaliah and Pribadi, K. K. (2013) 'Wahyudi Akmaliah Muhammad dan Khelmy K. Pribadi yang meneliti "Anak Muda, Radikalisme, dan Budaya Populer', Maarif, 8(132-153).

Muluk, H. (2016) 'Radikalisme dan Terorisme dalam Perspektif Psikologi Sosial'. Bandar Lampung.

Murtadlo, M. (2019a) Menakar Moderasi Beragama pada Perguruan Tinggi, Kemenag.go.id.

Murtadlo, M. (2019b) Seminari dan Pengembangan Moderasi Beragama: Kajian terhadap Seminari Al Kitab Asia Tenggara (SAAT) Malang. Jakarta. Puslitbang Penda
Mussafa, R. A. (2018) 'Konsep Nilai-nilai Moderasi dalam Al-Qur'an dan Implementasinya dalam Pendidikan Agama Islam (Analisis Al-Qur'an Surat Al-Baqarah ayat 143)', Skripsi Fakultas Ilmu Tarbiyah dan Keguruan Universitas Islam Negeri Walisongo Semarang.

Peter Chalk, Angel Rabasa, William Rosenau, L. P. (2010) 'The Evolving Terrorist Threat to Southeast Asia', Distribution. doi: RAND.

Qowaid, Q. (2013). Gejala Intoleransi Beragama Di Kalangan Peserta Didik Dan Upaya Penanggulangannya Melalui Pendidikan Agama Islam Di Sekolah. Dialog, 36(1), 71-86.

Sutrisno, E. (2019) 'Aktualisasi Moderasi Beragamadi Lembaga Pendidikan', Jurnal Bimas Islam, 12(1), pp. 323-348. doi: https://doi.org/10.37302/jbi.v12i2.113.

Zuly Qodir (2013) 'Perspektif Sosiologi tentang Radikalisasi Agama Kaum Muda', Maarif, 8(1), pp. 45-66. 